\title{
Literature and Medicine in the Nineteenth-Century Periodical Press
}




\section{Edinburgh Critical Studies in Romanticism}

Series Editors: Ian Duncan and Penny Fielding

\section{Available Titles}

A Feminine Enlightenment: British Women Writers and the Philosophy of Progress, 1759-1820

JoEllen DeLucia

Reinventing Liberty: Nation, Commerce and the Historical Novel from Walpole to Scott

Fiona Price

The Politics of Romanticism: The Social Contract and Literature Zoe Beenstock

Radical Romantics: Prophets, Pirates, and the Space Beyond Nation Talissa J. Ford

Literature and Medicine in the Nineteenth-Century Periodical Press: Blackwood's Edinburgh Magazine, 1817-1858

Megan Coyer

\section{Forthcoming Titles}

Ornamental Gentlemen: Literary Antiquarianism and Queerness in British Literature and Culture, 1760-1890

Michael Robinson

Following the Footsteps of Deep Time: Geological Travel Writing in Scotland, 1750-1820

Tom Furniss

Visit our website at: edinburghuniversitypress.com/seriesedinburgh-critical-studies-in-romanticism.html 


\section{Literature and Medicine in the Nineteenth- Century Periodical Press}

Blackwood's Edinburgh Magazine, 1817-1858

Megan Coyer 
Edinburgh University Press is one of the leading university presses in the UK. We publish academic books and journals in our selected subject areas across the humanities and social sciences, combining cutting-edge scholarship with high editorial and production values to produce academic works of lasting importance. For more information visit our website: edinburghuniversitypress.com

(C) Megan Coyer, 2017

Edinburgh University Press Ltd

The Tun - Holyrood Road, 12(2f) Jackson's Entry, Edinburgh EH8 8PJ

Typeset in 11/14 Adobe Sabon by

IDSUK (DataConnection) Ltd, and

printed and bound in Great Britain by

CPI Group (UK) Ltd, Croydon CR0 4YY

A CIP record for this book is available from the British Library

ISBN 9781474405607 (hardback)

ISBN 9781474405614 (webready PDF)

ISBN 9781474405621 (epub)

The right of Megan Coyer to be identified as the author of this work has been asserted in accordance with the Copyright, Designs and Patents Act 1988, and the Copyright and Related Rights Regulations 2003 (SI No. 2498). 